\title{
ACOUSTICAL ASPECTS OF THE RECONSTRUCTION OF A HISTORICAL BUILDING WITH CLOSED COURTYARD
}

\author{
${ }^{1}$ Valéria V. HORN*, ${ }^{2}$ Annamaria DUDAS \\ ${ }^{1,2}$ Department of Construction Materials and Technologies, Budapest University of \\ Technology and Economics, Müegyetem rkp. 3, Budapest, Hungary \\ e-mail: ${ }^{1}$ horn.valeria@met.bme.hu, ${ }^{2}$ dudas.annamaria@epito.bme.hu
}

Received 2 January 2019; accepted 1 July 2019

\begin{abstract}
The Szentgyörgyi-Horváth-house is one of the major historical buildings of Balatonfüred. The design of the reconstruction was preceded by detailed architectural historical study. The reconstruction of the building was realized by retaining the original structures. For the new function the building was equipped with an air-conditioning engine-room. The air conditioner is a significant source of noise for the apartments facing the courtyard of the building, due to its continuous operation. The acoustic examination of the enclosed yard was calculated with two different approaches. The distance-dependent approximation, which is usual for large halls, was approved. Building construction structures were determined based on the results to meet the acoustic requirements.
\end{abstract}

Keywords: Reconstruction of historical building, Sound protection against industrial noise, Acoustic design of an air-conditioning engine-room, Approximation of sound pressure level in a closed yard with diffuse sound field, Approximation of sound pressure level in a closed yard with distance dependency

\section{History of the Szentgyörgyi-Horváth-house}

Balatonfüred is a remarkable spa town on the Northern shore of Lake Balaton. The settlement started to show spectacular development from the beginning of the 1820's (during the Reform Era) [1]. Many holiday homes, hostels and other public institutions (stone theaters) were established in the area of the bathing-place. Major politicians and artists, members of the noble families have spent their holidays here and in the

\footnotetext{
${ }^{*}$ Corresponding Author
} 
vicinities. Palatine of Hungary, Archduke Josepf Habsburg visited the town with his family in 1821. The town was designated as 'Füred est ornamentum Regni Hungarie', namely 'Füred is an ornament of the Hungarian Kingdom' [2].

The cultural-historical interest of Szentgyörgyi-Horváth-house is that the first socalled 'Anna ball' was organized in honor of Anna Krisztina Szentgyörgyi-Horváth in 1825, which was followed by several balls during the Reform Era [3]. This was a major social event of the era. At the same time, it meant a national standout in the AustroHungarian Monarchy and became a national event [4]. The ball was not organized for a few years after the Hungarian War of Independence was defeated, but again from the 1860's [5]. Later the event was organized at a new location.

Art historian Klára Kovács made a study of the building's history [6]. Based on this study, the area was the property of the Benedictine Abbey of Tihany in the $18^{\text {th }}$ Century. The family of Szentgyörgyi-Horváth became the owner at the end of that century. The archives of the Szentgyörgyi-Horváth family are kept safe in the County Archives of Szombathely, from which it is known, that the builders were Zsigmond SzentgyörgyiHorváth and his brother-in-law, József Varasdy Gludovácz. The archival materials contain the entry, which certifies that the construction was managed by Magister Muralio.

The building was built in 1795-98 as a single-storey rest-house for the family's own use (Fig. 1). The Northern and Southern façade were built with corner bays, the Eastern main façade with central bay, which has the axis for the entrance (Fig. 2). Three large rooms were separated on the $1^{\text {st }}$ floor behind the main façade as it was proven by the architectural historical research of the walls. A few salesrooms have been built in the Northern wing. In the interior courtyard wing there were service premises and a rack.

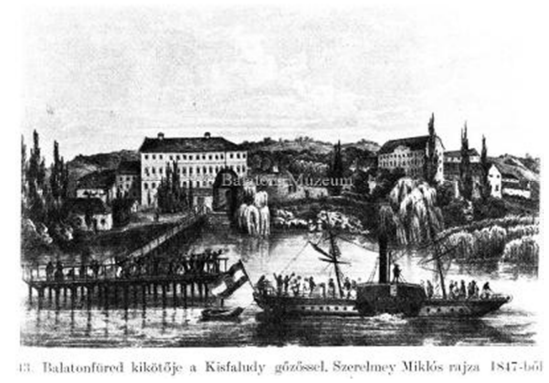

Fig. 1. Site view of the Horváth-house, drawing of Szerelmey Miklós in $\sim 1847$

(Source: Balaton Museum, Photo Archive)

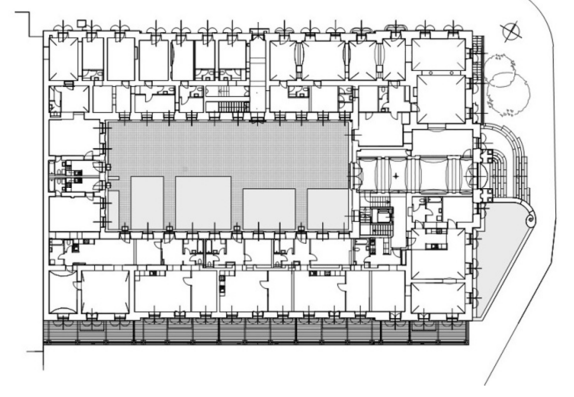

Fig. 2. Reconstruction ground plan of Horváth-house 2006, (Source: J. Kiss)

In 1834 fire destroyed the area. During the rebuilding the $2^{\text {nd }}$ floor and the still standing wooden pitched roof were realized. At that time there were 105 rooms available for the guests. The façades were retrofitted, as the main façade on the $1^{\text {st }}$ floor was lengthened by balconies, and a functional change of the doors and windows has also been made on the Northern elevation. It is known that the building was utilized as a spa hotel so-called Stefánia Court from The Austro-Hungarian Compromise of 1867. In 
the second half of the $19^{\text {th }}$ century until the middle of the $20^{\text {th }}$ century there were no major changes, despite of many changes in ownership.

In 1950, the building came under the ownership of the Mining Trade Union and lost many of the ornaments during the reconstructions at that time. Some of the load-bearing structures have been heavily altered, for example the rooms with surface spherical vaults, with a few exceptions, received reinforced concrete slabs. Some of the basement and ground floor rooms have the original vaults. On the ground floor and upstairs the central load-bearing walls were broken through in many places to create openings, thus internal reinforced concrete lintels were adjusted. The three large halls were partitioned into small rooms, the main staircase and the trolley passage were delocalized, the ornamental paintings were destroyed, and interior courtyards were built in the 1970's. There are no significant changes in the façade of the building, it preserves the original apportionment and courses. Horizontal façade proportioning is determined by the upstairs string cornices. On the ground floor the walls-strips are grooved. The windows were built into deeper wall-pans with plaster frame varying by level.

A new renovation started in the 1990's, but stopped for financial reasons.

At the beginning of the $21^{\text {th }}$ century, at long last, a full-scale reconstruction of the building was completed, which was preceded by wall layers research and art history research. For the reconstruction the architect was Judit Kiss, the interior designer was Júlia Kiss, Katalin Németh controlled the work by the side of historical preservation and the acoustic designer of the reconstruction was the Author, Valéria Horn.

\section{Original structures}

\subsection{Foundation and wall construction}

The building was made on quarry-stone-brick mixed foundation. In the basement there are brick and mixed natural stone-brick masonry walls, while on the upper floors solid bricks were used. The wall thicknesses in the basement and on the ground floor vary from $1.00 \mathrm{~m}$ to $0.84 \mathrm{~m}$ and to $0.65 \mathrm{~m}$, on the $1^{\text {st }}$ and $2^{\text {nd }}$ floor from $0.84 \mathrm{~m}$ to 0.68 $\mathrm{m}$ and to $0.45 \mathrm{~m}$.

There are brick arches over the openings of the basement, in the upper floors steel beams and monolithic reinforced concrete lintels were also constructed. The doors and windows on the ground floor and on the $1^{\text {st }}$ floor were built into niche. The forms of the arches are segmental or semi-circular. The research of the wall layers pointed out that the doors were fitted under brick arches. Because of the age of the building, wrought iron wall ties were used to stiffen the slab instead of ring beams. After the revealing it became evident that it was necessary to build ring beams in the planes of the string cornices and below them. With the new ring beams tension rods built into the vaults of the corner bays have become obsolete.

\subsection{Slab structure}

In the basement the slab is mostly segment barrel vaults with lunettes, in the reconstructed areas there are up-stand beamed monolithic reinforced concrete slabs. At 
some of the premises in the ground floor there is tension rod (tie rod) vault reinforcement. Above the other parts of the ground floor prefabricated ' $G$ ' beams are used with concrete trays or brick floor-block filling, with slag topping. Slabs above the ground floor are similar to the above mentioned structural solutions, but with mixed offal topping.

\subsection{Roof structure}

The roof structure is a particularly beautiful and valuable structure of the building. The roof structure consists of three different traditional pitched roof structures, but they fit well together. Above the two long sides of the building the roof frame is assembled together with horizontal tie beams. The principal frame posts are lengthened into the ridge, with a structure of stiffener rod and of collar ridge posts. The roof, according to a note on the rafter, was made by Master Fricz Meier in 1835. The roof structure above the entrance of the building is a three-post purlin roof structure with inclined struts, which was built probably due to the reconstruction of 1891. At the end of the building, at the connection of the two longitudinal half-roofs, a queen-post roof (two-post-roof) with collar beams was constructed with an in-completed couple roof with trimmer beam on the walls of staircase.

The wood conservation expert report classified the roof structure condition as good. Most of the failures could be tided over by trimming, only a few elements had to be replaced, and some components had to be stiffened with double-collar plank reinforcements. The roof structure received a wood protection treatment for increasing the lifetime. The cladding of the roof is traditional double tile solution on wooden battens.

\subsection{Exterior doors and windows}

The box-type traditional façade doors and windows were built into wall-reveals in the last century, replacing of the plank-framed structures, generally used in that building age. As traces of the installation of shutters were found during the survey in several places, the shutters were restored on the external plane. Windows and doors with thermal insulating glazing and increased sound reduction characteristic were built into the wall-reveals.

\subsection{Exterior shaping}

During the exploration, it was found that the color of the elevations was white, so the building got its original white color back. Façade doors and windows, as often used in the $18^{\text {th }}-19^{\text {th }}$ century, were treated with green staining.

\section{Architectural design aspects}

The Szentgyörgyi-Horváth-house, as a historical building, is still a dominant element of the historical quarter of Balatonfüred. The building received an apartment house function with the reconstruction. Complete retention and demonstration of the 
still existing building parts from the $18^{\text {th }}$ and $19^{\text {th }}$ century was a fundamental aspect during the reconstruction.

The reconversion of the original spatial relationships was also a key point of the restoration [7]. In this spirit, the entrance hall with the old passage was recreated, determining the original level of floor. The three-flight staircase got its original location back, but with an elevator in its stair-well.

The courtyard was converted into a relaxation garden, from where the apartments on the ground floor can be approached (Fig. 3). Upstairs flats open from the side corridor and all face the street.

It is the façade that mostly preserved the $18^{\text {th }}-19^{\text {th }}$ century's character. Thus, just small interventions were made that are in line with known representations existed in the second half of the $19^{\text {th }}$ century. For instance, the façade of Kisfaludy Street balconies with wooden structure are connected to the ground floor apartments (Fig. 4, Fig. 5). The balconies are connected by pergola. Balconies were established on the $1^{\text {st }}$ floor at the corner-reveals and on the even axes (Fig. 5).

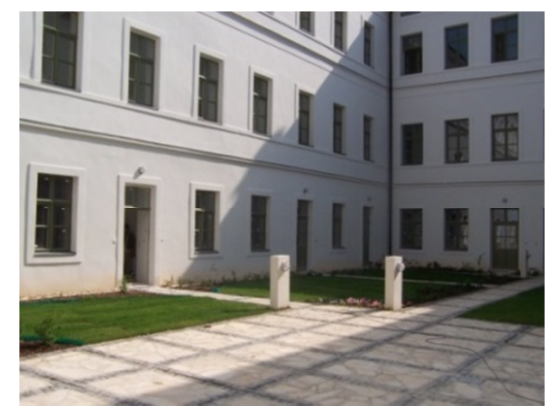

Fig. 3. Closed courtyard with the entrances of the apartments (Source: J. Kiss)

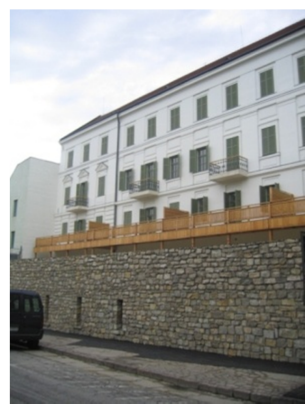

Fig. 4. Balconies on the 1st floor are at the corner-reveals and on the even axes (Source: J. Kiss)

The façade of Blaha Lujza Street got back its original design by demolishing portal structures built in the last century. Newly integrated elements are in harmony with Kisfaludy Street's portals. A characteristic feature of the façade design is that the doors and windows are fitted with blinds. On the one hand, this is consistent with the state of the early $20^{\text {th }}$ century; on the other hand it significantly reduces the solar load on the Southern façade as shading.

The condition of the external terrain in front of the main façade remained unchanged, as it is a public space (Fig. 6). The skirting of the building was completed and refurbished with solid limestone.

\section{Definition of acoustic tasks}

1. Verification of the façade for external noise. The relevant acoustic requirements had to be determined regarding the highest permissible noise load. Selection of 
the appropriate structures: design of the front windows and doors and the installation method for this reconstruction. Based on these characteristics the total sound reduction index had to be determined;

2. Design and verification of internal boundary structures for airborne sound insulation between rooms;

3. Verification of boundary structures, selection of cladding layers for impact sound insulation between rooms;

4. Design of water pipes and fittings to reduce equipment noise;

5. Design of sound protection against operating noises.

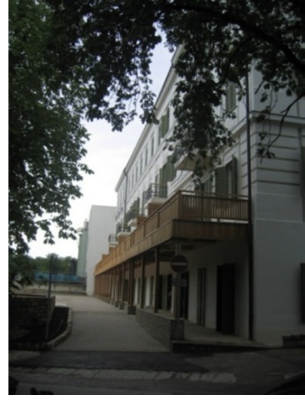

Fig. 5. Balconies with wooden structure connected to the ground floor apartments (Source: J. Kiss)

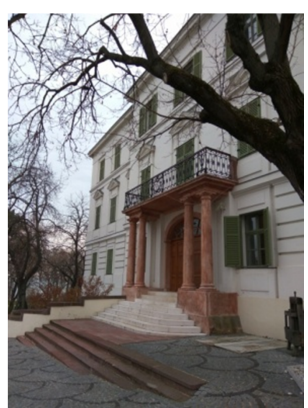

Fig. 6. Main façade with the entrance and balcony (Source: A. Dudás)

\section{Acoustic specifications for the area}

The Urban Construction Regulations [8] have taken the national regulations into account for the limits of environmental noises [9]. The area is considered as a curative area due to the closeness of the Balatonfüred State Heart Hospital.

The building is located in an especially quiet location, relatively far from busy roads. Neighboring Blaha Lujza Street is primarily a pedestrian zone, although it is possible to drive in from the direction of Medicinal Square, because there are a few small restaurants. The hospital's traffic is realized through the other neighboring Kisfaludy Street. The plane of the façade is $13 \mathrm{~m}$ away from the plot boundary that allowed building an underground garage in this width. In conclusion, the traffic noise is not significant.

The relevant Hungarian regulation [9] states the value of environmental noises calculated from the equivalent A-weighted sound level with correction factors, which refers to daytime and night time, namely the level of assessment $\left(L_{A M}\right)$.

The limit value $\left(L_{T H}\right)$ for the level of assessment $\left(L_{A M}\right)$ of noise from operating facilities in areas to be protected from noise is $45 \mathrm{~dB}$ daytime 6 a.m. - 22 p.m, $35 \mathrm{~dB}$ night time 22 p.m. - 6 a.m. according to the regulation. 
The limit value $\left(L_{T H}\right)$ for the level of assessment $\left(L_{A M}\right)$ of noise in building premises to be protected from noise belongs to the regulation in force for the noise generated by technical equipment inside buildings or traffic noise from outside the building it is 40 dB daytime 6 a.m. - 22 p.m., 30 dB night time 22 p.m. - 6 a.m. [9].

The above mentioned points 1-4 of acoustic design can be performed as usual. Designing the protection against operating noise of the climate control house, mentioned in the point 5 , is the most delicate part of the task.

The majority of the residential units are oriented to the streets and to the Medicinal Square, but the windows of the flats in the Western wing and some of the ground floor apartments are open to the inner courtyard. It was important to keep the noise load low at night in the residential units facing to the inner court if the windows were open, while other dwellings have closed windows at night and the cooling is continually working.

Consideration of the mentioned aspects required careful acoustic design. It was also important that the enclosed court shall serve really as a rest garden.

During the design process it had to be achieved that the noise generated in the airconditioning engine-room must be reduced to a required extent, therefore the boundary structures emanating noises to the environment had to be designed with adequate sound reduction index. The above mentioned requirements could be fulfilled with this method at the apartment house.

The air-conditioning engine-room is located above the Western wing of the building, in the attic space next to the boiler house, with a floor area of $42 \mathrm{~m}^{2}$ and a volume of about $200 \mathrm{~m}^{3}$ (see Fig. 7, partial section). There are two apartments underneath the engine-room. This was unfavorable from the installation point of view, but it could not be placed not above rooms, because elsewhere it would have required major restructuring of the pitched roof.

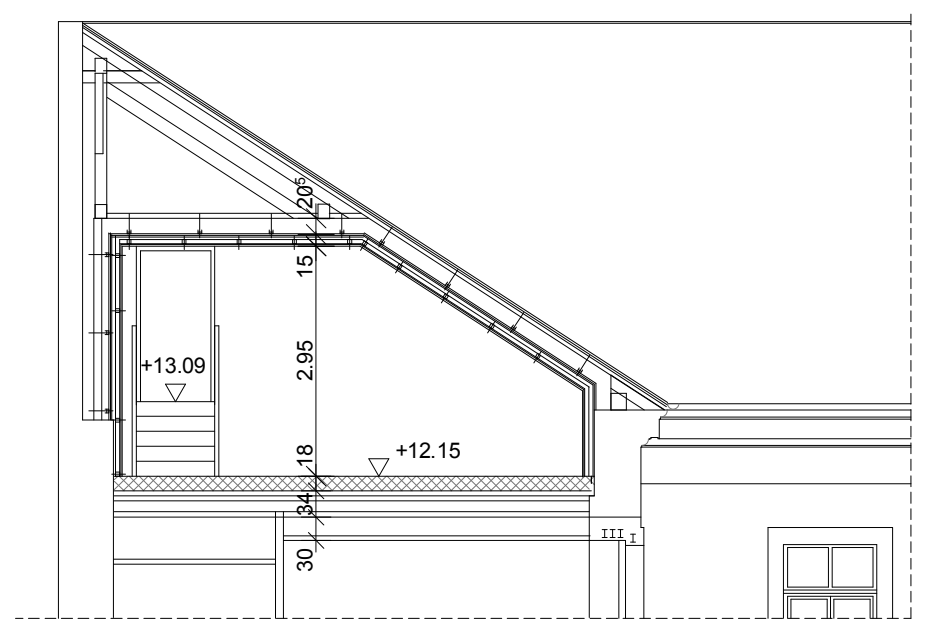

Fig. 7. Partial section of the roof at air-conditioning engine-room (Source: V. Horn) 
Thus, the rooms to be protected are: the rooms with the common slab, the other rooms facing the courtyards, and the inner rest garden. It should be noted that the rooms facing the courtyard are protected from the traffic noise of the street. From the direction of the structures to be protected - the façades with changing plains and the yard - the parapet wall of the air-conditioning engine-room can be seen, but the roof is not visible, so it is in its own shade. This can be considered as an additional damping.

The time of assessment is from 22 p.m. to 6 a.m. at night, due to night-time functioning equipment.

The source of the noise in the air-conditioning engine-room is two air-conditioners (CIATCOOLERLJA 400) with the associated fan. One of them is just a safety reserve.

The air conditioner is a source of impact sound and airborne sound, so the underlying slab had to be examined for vibration load and airborne-sound load. Vibration isolation was achieved by the establishment of a machine base, which improved the sound insulation of the slab at the same time.

The following sound routes were taken into account during the calculation of noise:

1. Refrigerator and fan noise - diffuse sound field in the engine-room;

2. Engine-room sound space - the top and side walls of the engine-room - noise emitted;

3. Engine-room sound space - slab - the rooms of the two apartments directly below;

4. Power out of the engine-room - parapet wall - the façade of the two flats directly below the engine room;

5. Power out of the engine room - parapet wall - other apartments with windows opening to the inner courtyards;

6. Power out of the engine room - inner yard - the ground floor of the inner courtyard.

Initial data: geometric dimensions, acoustic power of sound sources, sound reduction index of boundary structures from catalog or standard [10], spectrum adaptation terms (for different types of noise sources), size of air intake and the sound pressure level difference of the used noise reduction element from the mechanical documentation.

\subsection{Calculation of sound route in point 1 - refrigerator and fan noise}

A diffuse sound field is formed in the air conditioner engine-room [11]. Based on the catalog spectrum data, the sound pressure levels from the refrigerator and the fan had to be determined and summed according to the diffuse sound field approximation:

$$
L A E=10 \cdot \lg \left(\sum_{i=1}^{n} 10^{0.1 \cdot L W A, i}\right)+10 \cdot \lg \left(\frac{4}{A}\right)
$$

where the resultant $L A E$ is the operational noise $(\mathrm{dB}) ; L W A, i$ is the equivalent $A$ weighted sound level of the machine, which is corrected by the ground noise [12]; $A_{e}$ is 
the equivalent sound absorption surface of the room $\left(\mathrm{m}^{2}\right) ; i$ is the number of the machines:

$$
A=\sum_{i=1}^{n} \alpha i \cdot S i
$$

where $\alpha$ is the sound absorption coefficient; $S$ is the surface $\left(\mathrm{m}^{2}\right)$ according to [13]; $i$ marks the different constructs (wall, ceiling, door, window, etc.).

Dry-technology structures were built in front of the original bordering constructions of the air conditioner engine-room, and a vibration insulated machine base was built on the slab. The equivalent sound absorption coefficient were $\alpha=0.5$ for dry walls, $\alpha=0.75$ for suspended ceiling, and $\alpha=0.03$ for concrete.

\subsection{Calculation of sound route in point 2}

At the emitted total sound power level at the boundary structures of the engine-room - on the roof, on the parapet wall - the followings had to be taken into account:

The sloping roof plane and ceiling were designed as double shell structure. Frames have been made of cold-formed steel sections independent from rafters. As closure steel profile system was assembled perpendicularly to the frames with a 2 layer of plasterboard on both sides and $40 \mathrm{~mm}$ sound insulating glass fiber quilt filling. A polyurethane absorbing sheet was placed on the inner layer. In front of the parapet wall a wainscot was built on the frame of ribs. A glass fiber with a specific flow resistance of $r=6.5 \mathrm{kNs} / \mathrm{m}^{4}$ was placed between the ribs.

Determining the sound power level emitted from the structure the double tile roof cladding was ignored, because of the opened connection gaps between the elements of the cladding. The emitted sound power level on the structure is:

$$
L w=L A-R^{\prime}+10 \cdot\left(\frac{S}{A}\right),
$$

where $R^{\prime}$ is the in situ sound reduction index of the boundary structure (dB); $S$ is the surface of the boundary structure; $L A$ is the A-weighted noise of the machine [12], [14]. The emitted sound power was similarly calculated at the parapet wall, and the total sound reduction index of the boundary structure is derived from a summary of the sound reduction of the parapet wall and the wainscot.

The resultant emitted sound power from the roof, parapet wall and air inlet:

$$
\text { Lwe } \left.=10 \cdot \lg 10^{(0.1 \cdot L w 1+0.1 \cdot L w 2+0.1 \cdot L w a i}\right),
$$

where sound powers through the structures are $L w 1$ from the roof, $L w 2$ from the parapet wall, Lwai from the air inlet [12].

It should be noted that at the air intake a 2-m-long sound attenuator with mineral fiber lining was required to be installed. The penetration of air ducts and pipelines 
through the walls was also achieved by the installation of special prefabricated elements made of soft material.

\subsection{Calculation of sound route in point 3}

The engine-room is located above two apartments, but it affects only a part of both. The original slab was replaced with prefabricated concrete beam slab in this wing also. It was necessary to build a slab-independent machine base, which is standing on vibration-insulated springs, made of $18 \mathrm{~cm}$ thick reinforced concrete slab. This was built on special rubber vibration insulation for impact noise on floating slabs Composite Damping Material (CDM) vibration damping springs (dynamic stiffness $0.2 \mathrm{MN} / \mathrm{m}^{3}$ ). By incorporating this material the resonance frequency changed below $20 \mathrm{~Hz}$. The boiler machine base was designed similarly.

The sound pressure level on the common slab of the flats and the engine-room:

$$
L A=L A E-R^{\prime}+10 \cdot \lg \left(\frac{S}{A}\right)
$$

where $R^{\prime}$ is the in situ sound reduction index (only the sound insulation of the new monolithic reinforced concrete base was taken into account, which means some safety reserve); $S$ is the surface between the apartment and the engine-room; $A$ is the equivalent sound absorption surface of the room. It was considered for unfurnished condition, but a plasterboard ceiling with 0.5 acoustic absorption coefficient was designed in the affected room.

\subsection{Calculation of sound route in point 4}

The façade load is initiated from the sound pressure level at the upper part of the courtyard, passing through the boundary structure of the air-conditioning engine-room. There is no general computational method for the acoustic examination of the bounded but open spaces therefore it was assumed as a closed space. It was defined in two ways:

- In case 1, the sound pressure level of the yard was calculated by the diffuse sound field approximation from the sound pressure level of the end of the sound route 2 [12]:

$$
L p=L w-10 \cdot \lg \left(\frac{A}{4}\right)
$$

- In case 2, the distance-dependent approximation was used, which is usual for calculation of rooms not larger than $5000 \mathrm{~m}^{3}$ [15], [16],

$$
L p(d)=L w+10 \cdot \lg \left(\frac{1}{\theta \cdot d^{2}}+\frac{4}{A}\right)-D s h a d+K,
$$


where the solid angle $\Theta=2 \pi(\mathrm{sr})$; $d$ is the distance of the test point from the surface of sound emitting surface (m); $L W$ is derived from the calculation of the sound route 2, Dshad is the effect of the self-shading $(\mathrm{dB}) ; K$ is the correction factor $(\mathrm{dB})$, which is a combination of several noise sources limiting the impact of this.

The equivalent sound absorption surface was calculated with approximation of $\alpha=0.1$ for the inner courtyard with lawn and concrete covering, $\alpha=0.01$ for sound reflector hard plastered façade, $\alpha=0$ for windows, and $\alpha=1.0$ for the theoretic top of the courtyard. Of the two cases, the latter gave a higher value, so the study continued further with it.

The sound pressure levels entering through the façade wall and window were calculated in the usual way. The sound insulation of the façade wall was estimated based on the specific mass of the homogeneous single-shell structures $(R w \approx 23.7 *$ $\lg \left(\mathrm{m}^{\prime \prime}\right)$ - 9) [17]. The sound reduction index of the open window is 0 , of course,

$$
L p=L p(d)+10 \cdot \lg \left(\frac{S f \cdot 10^{-0.1 \cdot R w f}+S w i n \cdot 10^{-0.1 \cdot R w w i n}}{A}\right)
$$

where $S f$ is the solid façade of the given room $\left(\mathrm{m}^{2}\right) ; R w f$ is the sound reduction index of the façade; Swin is the surface of the window; Rwwin is the sound reduction index of the window.

The resulting sound pressure level in the apartments under the air-conditioning engine-room was determined by the logarithmic sum of the sound pressure levels entering through the ceiling and the façade. The value remains below the limit of the level of assessment. However, for the two apartments concerned, the calculation was one-data approximation, so a frequency-dependent (octave band test) had to be performed.

\subsection{Calculation of sound route in point 5 and 6}

These calculations were neglected, because in the two apartments under the airconditioning engine-room a sound pressure level was less than $30 \mathrm{~dB}$, and this value further decrease in the case of distant rooms and the courtyard.

\section{Summary and conclusion}

With the chosen structures the construction of the air-conditioning engine-room complied with the acoustic standards and requirements in force. In the calculation the requirements are also fulfilled for the less favorable alternative also. At the same time, the structure has some reserves.

Approaching the enclosed but open inner courtyard as a closed space and the computation method used in enclosed spaces demonstrated to be correct and proved by good operation of the building. 


\section{Open Access statement}

This is an open-access article distributed under the terms of the Creative Commons Attribution 4.0 International License (https://creativecommons.org/licenses/by/4.0/), which permits unrestricted use, distribution, and reproduction in any medium, provided the original author and source are credited, a link to the CC License is provided, and changes - if any - are indicated. (SID_1)

\section{References}

[1] Wettstein D. Hystoricanalysis of regional planning of Balaton, Pollack Periodica, Vol. 8,No. 1, 2013, pp. 141-152.

[2] Lichtneckert A. (Ed.) The history of Balatonfüred and Balatonarács, (in Hungarian) Veszprém, Municipality of Balatonfüred City, 1999.

[3] Zákonyi F. Balatonfüred, additives to the history of Balatonfüred from the beginning to 1945, (in Hungarian) Veszprém, 1988.

[4] Hungarian language selection (in Hungarian), Helikon, 1987, based on the original English language source Paget J. Hungary and Transylvania; with remarks on their condition, social, political and economical, Vol. 1, J. Murray, London, 1839.

[5] Balatonfüred Diary 1860 - Local History Museum,

[6] Kovács K. Study of the building's history, Manuscript - Institute for Art History of the Hungarian Academy of Sciences, Research Center of Humanities, 2005.

[7] Kovács-Andor K. The architectural renewal of the main square of Kecskemét and its surrounding area, Pollack Periodica, Vol. 9, No. 3, 2014, pp. 119-126.

[8] Local construction regulations of city Balatonfüred, (in Hungarian) 2006.

[9] 27/2008 Decree (XII.3.) KvVM-EüM, Joint decree on the establishment of environmental noise and vibrational load limits (Annex 1) (in Hungarian), 2008.

[10] DIN 4109 Sound insulation in buildings; requirements and testing, (in German) German Institute for Standardization, 1989.

[11] VDI 2571 Sound Radiation from Industrial Buildings (in German) Schallabstrahlung von Industriebauten, Verein Deutscher Ingenieure, 1976.

[12] Reis F. Basics of building acoustics, (in Hungarian) Terc, Budapest, 2003.

[13] MSZ EN 12354-6, Building acoustics, Estimation of acoustic performance of buildings from the performance of elements, Part 6: Sound absorption in enclosed spaces, European Standards, 2004.

[14] MSZ EN ISO 12354-3, Building acoustics, Estimation of acoustic performance of buildings from the performance of elements, Part 3: Airborne sound insulation against outdoor sound, International Organization for Standardization, 2000, (standard withdrawn in 2018).

[15] MSZ EN ISO 12354-4, Building acoustics, Estimation of acoustic performance of buildings from the performance of elements, Part 4: Transmission of indoor sound to the outside, International Organization for Standardization, (in Hungarian) 2003, (standard withdrawn in 2018).

[16] Hunyadi Z., Juharyné Koronkai A., Reis F. Building acoustics, (in Hungarian) (lecture notes)Müegyetemi Kiadó, Budapest, 1999.

[17] Fasold W., Kraak W., Schimer W. Acoustic handbook (in German) VEB Verlag Technik, Berlin, 1984. 